\title{
Slipped capital femoral epiphysis
}

\section{A report of 4 cases occurring in one family}

\author{
J.F. Moreira ${ }^{1}$, M.C. Neves ${ }^{2}$, G. Lopes ${ }^{3}$, A.R. Gomes ${ }^{2}$ \\ ${ }^{1}$ Department of Orthopaedics, Hospital Curry Cabral, Lisbon, Portugal \\ 2 Department of Orthopaedics, Hospital Santa Maria, Lisbon, Portugal \\ ${ }^{3}$ Department of Orthopaedics, Hospital do Barreiro, Portugal
}

Accepted: 6 May 1997

\begin{abstract}
Summary. We describe slipped capital femoral epiphysis in 4 members of a black, obese family, who were all first-degree relatives. The aetiology of slipped capital femoral epiphysis is unknown, although it is thought to be multifactorial. Genetic predisposition and environmental factors have been associated with the condition. A familial incidence with at least two cases in the same family has been reported. In epidemiological studies, this incidence ranges from $3 \%$ to $35 \%$. Our cases were investigated in an attempt to find a possible aetiological genetic factor. A genetic predisposition with an autosomal dominant pattern of transmission is suggested, although environmental variables must be considered as provocative factors.
\end{abstract}

Resumé. L' etiologie de l'épiphysiolyse fémorale supérieure (EFS) n'est pas connue, mais, en tous cas, elle parait multifactorielle. La prédisposition génétique et les conditions environmentales ont été associées avec l'EFS. L' incidence familiale avec au moins deux cas dans la même famille a êté rapporté dans la littérature de $3 \%$ à $35 \%$. Un cas de EFS chez 4 sujets d'une famille de race noire, tous obèses, a été étudié de façon à montrer un éventuel facteur génétique etiologique. On suggère une prédisposition génétique avec un élément dominant autosomique sans oublier les differents facteurs environmentaux comme facteurs prédisposants.

\section{Introduction}

Familial incidence of slipped capital femoral epiphysis (SCFE), with at least two cases in the same fami-

Reprint requests to: M.C. Neves, Department of Orthopaedics, Children's Service, Hospital de Santa Maria, P-1699 Lisboa Codex, Portugal ly, has been reported by a number of authors with an incidence of from $3 \%$ to $35 \%[1,2,6,8,10-15,19$, $20,23,26,27,29,31-35,37-39,42]$. Oschner described a family with SCFE in 10 members [27]. Since many cases of SCGE do not have symptoms the figures may be underestimated, with the true familial incidence being higher [15, 28, 30, 31].

The familial clustering suggests either a predisposing hereditary trait $[15,27,31]$ or a provocative environmental factor common to the family [15, 21, 31], or both. The incidence of SCFE has been found to be higher in blacks than whites [22, 24, 42] and among males than females $[6,16-18,20,22,24,28,38,42]$. This increased incidence further suggests a genetic factor in SCFE, although interactive environmental factors might also be involved $[9,16,21,25]$. A different male:female ratio in the familial group (1:2/1) against the nonfamilial group (4:1) is typical of a condition showing a genetic effect [31].

The form of inheritance in some families appears to be an autosomal dominant with variable penetrance $[15,27,30,31]$. However, some authors consider that familial inheritance is of no aetiological significance, and that environmental factors play the major role $[36,38]$. Some familial cases of SCFE could be due to environmental factors affecting the whole family [21], such as a rural life, where heavy work may lead to repeated or violent trauma of the epiphysis $[15,16$, 31].

The occurrence of SCFE in several, or all, of the siblings of one parent is less often reported and strongly suggests a familial vulnerability. Cases of SCFE in a black family, as in the present report, has only been described once [37], although the increased incidence of slipped epiphysis in blacks has been recognised. 


\section{Case reports}

Case 1

A boy, 12 years of age, of black race (from the Cape Verde Islands) complained of pain in the right hip and limping for a month with no apparent cause. He had limited and painful internal rotation and abduction. The patient was admitted to hospital in May 1995. Radiographs showed bilateral SCFE (Fig. 1). He was obviously obese with some signs of puberty (genitalia slightly enlarged, lightly pigmented downy pubic hair).

\section{Case 2}

A girl, 11 years of age, black and the sister of case 1, developed symptoms 8 months later. She was admitted in February 1996. Radiographs showed SCFE in the right hip (Fig. 2). She was obese with no signs of puberty (prepubertal breasts, infantile genitalia, no pigmented pubic hair).

\section{Case 3}

A girl, 6 years of age, black and a half-sister to cases 1 and 2, with the same father but a different mother, had experienced chronic pain in both hips with limited internal rotation, but had never sought medical attention. She was extremely obese and sexually mature. Radiographs revealed bilateral old SCFE (Fig. 3).

\section{Case 4}

A man, 40 years of age, and father of the cases 1,2, and 3, had never had hip symptoms or functional limitation, but radio-
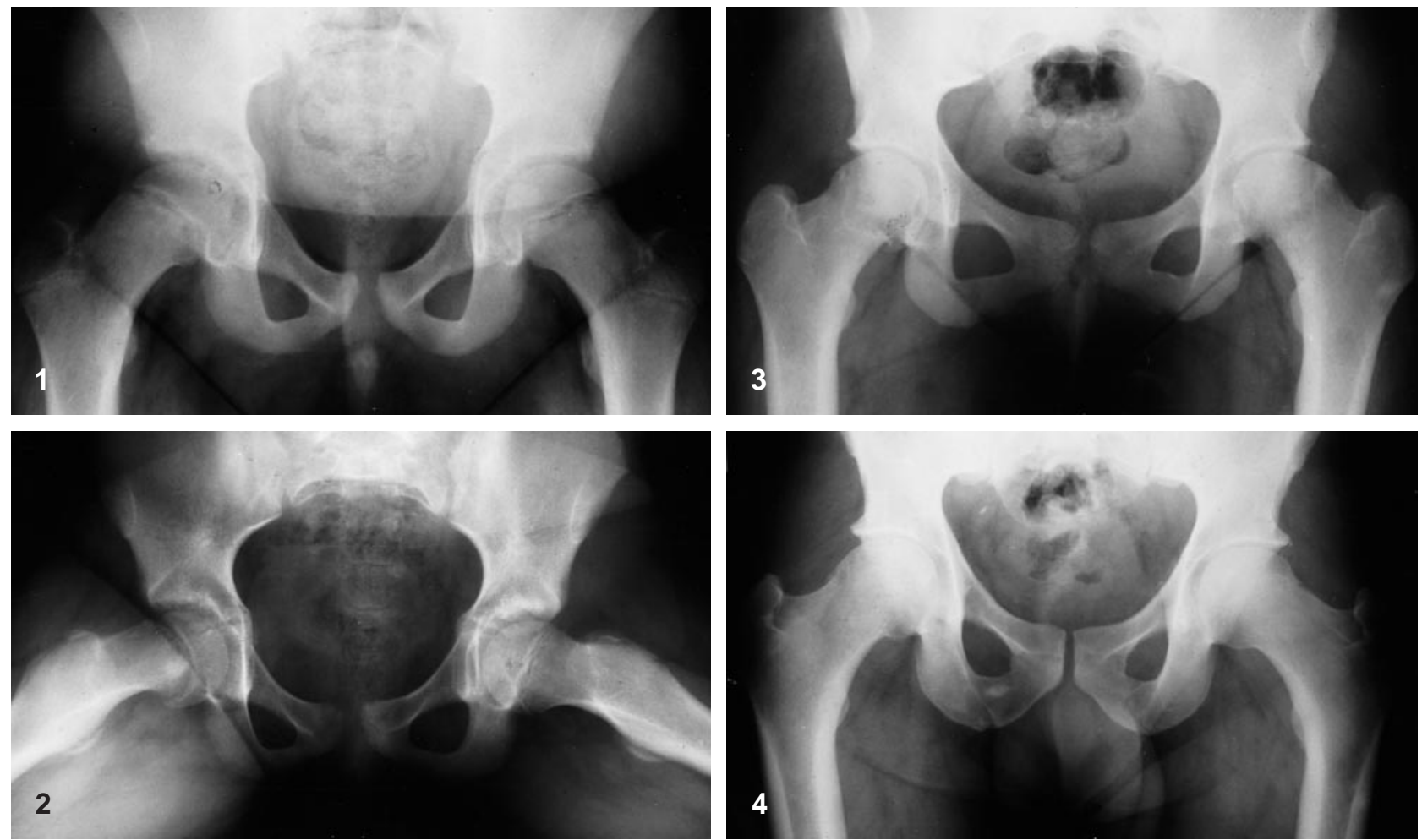

Fig. 1. Anteroposterior radiograph of the pelvis of case 1 showing bilateral grade I SCFE

Fig. 3. Anteroposterior radiograph of the pelvis of case 3 showing bilateral old SCFE

Fig. 4. Anteroposterior radiograph of the pelvis of case 4 showing minimal old SCFE on the right side

Fig. 2. Lateral radiographs of the upper femora of case 2 showing grade I SCFE of the right hip

Table 1. Hormonal imbalances found in the three siblings

\begin{tabular}{|c|c|c|c|c|c|c|c|c|c|c|}
\hline \multirow{2}{*}{$\begin{array}{l}\text { Identification: } \\
\text { Hormone levels } \\
\text { (serum) }\end{array}$} & \multicolumn{2}{|c|}{$\begin{array}{l}\text { Case } 1 \\
\text { male, } 12 \text { y. }\end{array}$} & \multicolumn{2}{|c|}{$\begin{array}{l}\text { Case } 2 \\
\text { female, } 11 \text { y. }\end{array}$} & \multicolumn{2}{|c|}{$\begin{array}{l}\text { Case } 3 \\
\text { female, } 16 \text { y. }\end{array}$} & \multicolumn{2}{|l|}{$\begin{array}{l}\text { Case } 4 \\
\text { (father) }\end{array}$} & \multicolumn{2}{|c|}{$\begin{array}{l}\text { Mother of } \\
\text { cases } 1 \text { and } 2\end{array}$} \\
\hline & Results & $\begin{array}{l}\text { Refer. } \\
\text { values }\end{array}$ & Results & $\begin{array}{l}\text { Refer. } \\
\text { values }\end{array}$ & Results & $\begin{array}{l}\text { Refer. } \\
\text { values }\end{array}$ & Results & $\begin{array}{l}\text { Refer. } \\
\text { values }\end{array}$ & Results & $\begin{array}{l}\text { Refer. } \\
\text { values }\end{array}$ \\
\hline SHBG (nmol/l) & 20.6 & $\begin{array}{l}\text { P: } 55-110 \\
\text { A: } 10-70\end{array}$ & 18.9 & $\begin{array}{l}P: 55-100 \\
A: 20-100\end{array}$ & 19.6 & $\begin{array}{l}\text { P: } 55-100 \\
\text { A: } 20-100\end{array}$ & 21.8 & $\begin{array}{l}\text { P: } 55-100 \\
\text { A: } 10-70\end{array}$ & 29.1 & $\begin{array}{l}\text { P: } 55-100 \\
\text { A: } 20-100\end{array}$ \\
\hline Insulin $(\mathrm{mU} / \mathrm{ml})$ & 29.6 & $3-17$ & 20.4 & $3-17$ & 20.4 & $3-17$ & 10.1 & $3-17$ & 14.3 & $3-17$ \\
\hline
\end{tabular}

Reference values for sex, age and sexual development: P: pre-pubertal values; A: adult values; SHBG: sex hormone bind globulin 
graphs revealed minimal old SCFE in the right hip (Fig. 4). He had no other siblings.

The mother of cases 1 and 2 was also studied. She was 40 years of age and had never had hip symptoms. Radiographs showed no signs of old SCFE. She had no other siblings. The mother, 35 years of age, of the other child had no present or past hip symptoms, and radiographs showed no signs of old SCFE. She has two other children from another father with no signs of SCFE. There is no consanguinity among the parents of the three siblings.

Laboratory data from the 4 cases showed that subtle hormonal imbalances were present in the sex hormone bind globulin (SHBG) and the insulin in 3 of the siblings (Table 1).

\section{Discussion}

Several investigations and case reports have emphasised the occurrence of more than one case of SCFE in the same family. Genetic and environmental conditions have been implicated. Probably the susceptibility of a given individual to SCFE is influenced by genetically determined response to his environment. Different patterns of transmission of this susceptibility have been suggested including multifactorial, Xlinked dominant, autosomal dominant with variable penetrance and autosomal recessive [15, 27, 31]. In the present black family, all 3 siblings have SCFE, are obese and showed subtle hormonal imbalances with low levels of SHBG and increased insulin levels, probably related to obesity $[3-5,7,40,41]$. This underlies a possible interaction between endocrine imbalance and obesity in SCFE. It seems that in the present family, obesity or hormonal imbalance, whatever the cause, do not fully explain the increased incidence of SCFE. The father, with minimal old SCFE, having three affected children from two unaffected wives, suggests an autosomal dominant form of inheritance. In some families, this pattern of transmission seems more likely to occur than a multifactorial form of inheritance [15, 27, 31], and an important genetic predisposition may exist with a clear pattern of transmission; the role of environmental factors as triggering conditions is of varying importance, but remains unknown. As previous authors have pointed out, in families with more then one case of SCFE, it is important to be aware of the increased risk that subsequent children may be affected.

\section{References}

1. Allen CPF, Calvert PT (1990) Simultaneous slipped upper femoral epiphysis in identical twins. J Bone Joint Surg [Br] 72:928-929

2. Beck Von E (1968) Ein Beitrag zum familiären Vorkommen der Epiphysiolysis capitis femoris. Z Orthop 105:112-118

3. Bernasconi D, Del Monte P, Meozzi M, Randazzo M, Marugo A, Badaracco B, Marugo M (1996) The impact of obesity on hormonal parameters in hirsute and non-hirsute women. Metabolism 45:72-75

4. Bjorntorp P (1995) Endocrine abnormalities of obesity. Metabolism 44[9 Suppl 3]:21-23

5. Botwood N, Hamilton Fairley D, Kiddy D, Robinson S, Frank S (1995) Sex hormone-binding globulin and female reproductive function. J Steroid Biochem Mol Biol 53:529-531

6. Burrows HJ (1957) Slipped upper femoral epiphysis. Characteristics of a hundred cases. J Bone Joint Surg [Br] 39:641-658

7. Drent ML, Van-der-Veen EA (1995) Endocrine aspects of obesity. Neth J Med 47:127-136

8. Droumaget MPM (1959) Contribution l'étude de l'epiphysiolise de la hanche de l'adolescent et de ses séquelles (95 observations) - Thesis. In: Thésis de la Université de Bordeaux. Bordeaux: Imprimeries Delmas 1-96 (Thesis no 171)

9. Ferguson AB, Howorth MB (1931) Slipping of the upper femoral epiphysis. JAMA 87:1867-1870

10. Fittig O (1909) Die Epiphysenlösung des Schenkelhalses und ihre Folgen. Arch Klin Chir 89:912-948

11. Francillon MR (1956) Zur Prophylaxe der Arthrosis deformans coxae: Diagnose und Therapie der Epiphysiolisis capitis femoris. Schweiz Med Wochenschr 86:167

12. Gajraj HAR (1986) Slipped capital femoral epiphysis in identical twins. J Bone Joint Surg [Br] 68:653-654

13. Gorin RL (1977) Slipped capital femoral epiphysis in identical twins: report of a case. J Am Osteopath Assoc 77:124-128

14. Green WT (1945) Slipping of the upper femoral epiphysis. Arch Surg 50:19-33

15. Hagghlund G, Hansson LI, Sandstrom S (1986) Familial slipped capital femoral epiphysis. Acta Orthop Scand 57:510-512

16. Hansson LI, Hagghlund G, Orderberg G (1987) Slipped capital femoral epiphysis in Southern Sweden 1910-1982. Acta Orthiop Scand 58 [Suppl 226]:1-67

17. Henrickson B (1969) The indicence of slipped capital femoral epiphysis. Acta Orthop Scand 40:365-372

18. Howorth B (1966) Etiology - slipping of the capital femoral epiphysis. Clin Orthop 48:49-52

19. Irwin CG (1946) News notes: unilateral adolescent coxa vara. J Bone Joint Surg 28:653

20. Jerre T (1950) A study in slipped upper femoral epiphysis with special reference to late functional and roentgenological rsults and to the value of closed reduction. Acta Orthop Scand 6[Suppl]:1-157

21. Kelsey JL (1973) Epidemiology of slipped capital femoral epiphysis: a review of the literature. Pediatrics 51: 1042-1050

22. Kelsey JL, Keggi KJ, Southwick WO (1970) The incidence and distribution of slipped capital femoral epiphysis in connecticut and Southwestern United States. J Bone Joint Surg [Am] 52:1203-1216

23. Kirmisson ME (1918) Coxa vara et obésité. Bull Acad Méd (Paris), 3rd series 79:183-193

24. Loder RT et al. (1996) The demographics of slipped capital femoral epiphysis. An international multicenter study. Clin Orthop 322:8-27

25. Loder RT et al. (1996) A worldwide study on the seasonal variation of slipped capital femoral epiphysis. Clin Orthop 322:28-36

26. Montskó P, Dejong T (1995) Slipped capital femoral epiphysis in 6 of 8 first-degree relatives. Acta Orthop Scand 66:511-512

27. Ochsner PE, Razavi R, Schinzel A (1977) Epiphysiolisis capitis femoris mit wahrscheinlich unregelmäßig dominantem Erbgang. Bericht über eine Familie mit 10 Fällen. Z Orthop 115:840-847

28. Ordeberg G, Hansson LI, Sandstrom S (1984) Slipped capital femoral epiphysis in Southern Sweden. Clin Orthop 191:95-104

29. Pacher W (1944) Familiäres Auftreten von Varusdeformität und Epiphysenlösung des oberen Femurendes. Z Orthop 75:80-85

30. Rennie AM (1967) Familial slipped upper femoral epiphysis. J Bone Joint Surg [Br] 49:535-539 
31. Rennie AM (1982) The inheritence of slipped femoral epiphysis. J Bone Joint Surg [Br] 64:180-184

32. Ruther H (1954) Ursachen und Behandlung der jugendlichen Hüftkopflösung. Z Orthop 84 [Suppl]:33-38

33. Saalmann E (1926) Zur traumatischen Entstehung der Coxa vera adolescentium vom Standpunkt des Unfallbegutachters. Monatschr Unfallheilkd 33:108-111

34. Schreiber A, Schmied HR (1968) Beitrag zur Kenntnis der Epiphysiolisis capitis femoris; familiar gehäuftes Vorkommen. Z Orthop 104:368-375

35. Schwenkert E (1957) Zur Frage der operativen oder konservativen Behandlung der jugendlichen Hüftkopflösung (Coxa vera epiphysarea). Z Orthop 88:488-502

36. Scott JC (1956) Displacement of the upper epiphysis of the femur. In: Platt $\mathrm{H}$ (ed) Modern trends in orthopaedics (2nd series) Butterworth, London, pp 246-267
37. Smith WS (1955) Slipped upper femoral epiphysis in siblings. Ohio St Med J 51:1200

38. Sorensen KH (1968) Slipped upper femoral epiphysis. Clinical study in aetiology. Acta Orthop Scand 39: 499-517

39. Thrap-Meyer H (1940) Epiphysiolysis capitis in two generations. Acta Orthop Scand 11:1-10

40. Toscano V, Balducci R, Bianchi P, Guglielmi R, Mangiantini A, Sciarra F (1992) Steroidal and non-steroidal factors in plasma sex hormone binding globulin regulations. J Steroid Biochem Mol Biol 43:431-437

41. Walker M (1995) Obesity, insulin resistance, and its link to non-insulin-dependent diabetes mellitus. Metabolism 44 [Suppl 3]:18-20

42. Wilson PD, Jacobs B, Schecter L (1965) Slipped capital femoral epiphysis. An end result study. J Bone Joint Surg [Am] 47:1128-1145 